\title{
INTERRELATIONS BETWEEN TOURISM OFFER AND TOURISM DEMAND IN THE CASE OF FARM TOURISM IN SLOVENIA
}

\author{
Dejan Cigale, Barbara Lampič, Irma Potočnik-Slavič ${ }^{1}$
}

Received 20 November 2012; Accepted 20 September 2013

\begin{abstract}
In Slovenia, farm tourism is among the most important supplementary activities on farm. On the other hand, its role within tourism sector is rather modest. The paper approaches the phenomenon of farm tourism from tourism supply and demand perspectives. Employed qualitative methods involved farm tourism holders and potential tourists on farm. The results have pointed out that the occurrence of tourist farms is primarily the result of farmers' needs and opportunities, and only on the second place of expressed demand of tourism market. Farm tourism supply and demand factors are interrelated in a rather complex way. Supply is only selectively influenced by (perceived) demand since farm tourism providers stick to extant idea/image of farm tourism and they are not putting it in question. In this way they also affect tourism demand since they shape a specific construct/image of farm tourism which attracts only some types of tourists.
\end{abstract}

Key words: farm tourism, rural areas, tourism demand, rural development, Slovenia

Izvleček: Turizem na kmetiji je v Sloveniji med najpomembnejšimi dopolnilnimi dejavnostmi. Po drugi strani je njegova vloga $v$ okviru turizma precej skromna. Prispevek obravnava turizem na kmetiji tako z vidika turistične ponudbe kot povpraševanja. Izvedena je bila anketna raziskava med člani kmečkih gospodinjstev na turističnih kmetijah, pa tudi intervjuji z njimi. Poleg tega je bilo opravljeno anketiranje potencialnih turistov na turističnih kmetijah. Rezultati so opozorili, da je razporeditev in ponudba turističnih kmetij $v$ prvi vrsti odvisna od potreb in pričakovanj lastnikov kmetij. Ponudba in povpraševanje turističnih kmetij sta tako povezani na precej zapleten način. Povpraševanje le selektivno vpliva na ponudbo, saj ponudniki tovrstnih storitev večinoma oblikujejo/gradijo na obstoječi podobi. Na ta način tudi vplivajo na oblikovanje specifične podobe turizma na kmetiji, ki (ne)privlači določene vrste turistov.

Ključne besede: turizem na kmetiji,podeželska območja, turistično povpraševanje, razvoj podeželja, Slovenija

\footnotetext{
${ }^{1}$ University of Ljubljana, Faculty of Arts, Department of Geography, Aškerčeva 2, SI-1000 Ljubljana; Dejan Cigale, Ph. D., e-mail: dejan.cigale@ff.uni-li.si; Barbara Lampič, Ph. D., e-mail: barbara.lampic@ff.uni-lj.si; Irma Potočnik Slavič, Ph. D., e-mail: irma.potocnik@ff.uni-lj.si
} 


\section{Introduction}

As agriculture has come under increasing pressure to diversify, pluriactivity has represented important pillar supporting farming, making it possible for farms that otherwise would have been forced to disappear to stay in business (Jervell, 1999; Kinsella et al., 2000; Van der Ploeg et al., 2000; Brandth, Haugen, 2011). These pillars involve a range of activities both on and off the farm, farm tourism being one of them. Indeed, tourism has been widely promoted as a development strategy for rural areas seeking to replace declining primary industries such as agriculture (Cawley, Gilmor, 2008; Storey, 2004; Woods, 2011). Farm tourism is a form of tourism with a long history (Nilsson, 2002; Hummelbrunner, Miglbauer, 1994; Béteille, 1996), but its more intensive growth took place in the post-World War Two era. It started to attract more attention only in the last decades. New forms of farm tourism in Europe are also the consequence of new agriculture policy in the EU (Nilsson, 2002).

Different terms are used to denote this form of tourism, e.g. farm tourism, agritourism, agritourism, farm-based tourism, farm-based rural tourism (e.g. Embacher, 1994; Lane, 1994; Sharpley, Vass, 2006; Sznajder et al., 2009; Sidali, 2011), etc. Differences between the meanings of these terms are often very unclear or even nonexistent. In our paper, in the first part terms farm tourism and agritourism will be partly used as synonyms, while in the second part, dealing with the situation in Slovenia, term farm tourism will be used.

Usually farm tourism is understood as a part of rural tourism (Nilsson, 2002; Phillip et al., 2010; Busby, Rendle, 2000). The term is difficult to define because it comprises a range of activities (Busby, Rendle, 2000). Normally a working farm is expected (e.g. Demonja, Ružić, 2010), although some authors (e.g. Phillip et al., 2010) consider also forms of agritourism without a working farm. According to Béteille (1996) the concept of agritourism includes all recreational and tourist activities initiated by farmer for accommodation or diversion of paying guests, usually of urban origin. Often in defining agritourism focus is on the relation between tourism and agriculture or on the links between both. Sznajder et al. (2009) define agritourism as "tourist activity whose aim is to familiarize oneself with farming activity and recreation in an agricultural environment." Although tourism on farm necessarily comes into some form of contact with agriculture, the level of contact tourists have with agricultural activities can vary considerably (Phillip et al., 2010). In the opinion of Dubois and Schmitz (2012) the presence or absence of agricultural activity and contact (or absence of it) of tourists with this activity allow differentiation of farm tourism and agritourism. On the other hand, the presence of agricultural attributes is not necessarily of greater importance for tourists (Fleischer, Tchetchik, 2005).

Farm tourism has some specific features, e.g. the interaction between the host's private life and the guest's experiences (Nilsson, 2002), the opportunity to become familiar with agricultural occupations, local products and traditional cuisine (Dubois, Schmitz, 2011), the possibility of participation in the process of food production, in the life of a rural family and in a rural community (Sznajder et al., 2009), etc. These features are of a varying importance to tourists.

According to Farmaki (2012) tourists travel to rural areas for various reasons - a need to escape or to relax, attraction of the cultural/religious or natural attributes, interest in the rural setting, wish "to escape from the city", etc. No tourist interviewed during the research expressed interest in seeking 'authenticity' or 'traditionality'; the primary purpose of visit to the rural area was interaction with nature and culture (Farmaki 2012).

Of course, rural tourists are not a homogenous group (see Kastenholz et al. 1999; Frochot 2005; Molera, Albaladejo 2007, etc.). E.g. Kastenholz et al. (1999) identified four tourist segments according to tourists' main benefits sought. Two of these segments are more interested in socializing and entertainment. One of the two is more interested in cultural offerings, whereas the second one values more environmental aspects and peace and quiet. The third segment is performed by enthusiasts of authenticity, culture, tradition, and peace and quiet. The fourth segment is valuing a peaceful and unpolluted environment (Kastenholz 1999). Differences between tourists are related to various factors. In regard to farm tourism it has been found that differences in farm tourism participation are related to tourists' age, gender and family circumstances (i.e. presence of children) (Blekesaune, Brandth, Haugen 2008). 
So far, farm tourism has been studied from different viewpoints and with a focus on different topics in various countries and regions, e.g. in Southern Germany (Oppermann, 1996), Spain (Cánoves at al., 2004), Wallonie (De Myttenaere, 2005; Dubois, Schmitz, 2011), Austria (Gattermayer, 2006), Gorenjska region in Slovenia (Krišelj, 1981), Lower Silesia (Grykień, 1999), and Croatia (Lukić, 2002), to mention just a few. Also some comparative research of the farm tourism in different countries has been made (Sidali, 2011; Schmitz, Potočnik-Slavič, 2012). These researches have shown that situation of farm tourism and circumstances in which it has developed and in which operates often differ a lot between countries. The same holds true for its offer and tourism demand. In the majority of cases, the role of farm tourism in tourism industry is rather modest - in terms of accommodation capacities and numbers of tourists although by no means insignificant (Nilsson, 2002; Solsona Monzonís, 2006).

Supporting the agricultural development is of great importance for maintaining cultural landscape and promoting rural development. Tourism on farm is often recognized as sustainable tourism (Hardy, 2001). As such, it has an important role for sustainable rural development. Within farming, organic farming is based on the most sustainable agricultural practices. Accordingly, links between organic farming and tourism are of a special interest and have already been studied (e.g. Choo, Jamal, 2009). The organic farming brings some effective answers to current environmental, social and economic issues of rural development. It ensures a higher level of public goods, such as soil quality and biodiversity (Stolzeet al., 2000; Mäderet al., 2002; Bengtsson et al., 2005; Fließbachet al., 2007). Furthermore, it contributes to sustainable rural development, for example by creating more jobs (Morrison et al., 2005; Lobleyet al., 2005). Organic producers and their families are also more satisfied with work on the farm (Gassneret al., 2008; Shrecket al., 2006). Often we can say that organic farming acts as a catalyst for innovation in rural development (Schäfer, 2007; Schmidet al., 2004). On the other hand, it also satisfies the needs of a growing segment of consumers who demand organic food (Garcia, de Magistris, 2007; Selfet al., 2008; Slabe et al., 2011).

\section{Research focus and methods}

Data on farm tourism in Slovenia are very scarce, although some basic information is collected by Statistical Office of the Republic of Slovenia (SORS; data on tourist beds, tourist arrivals and bed-nights) and Ministry of Agriculture and Environment (Register of supplementary activities on farm). Therefore, it has been necessary first to collect the data, which could facilitate more thorough study of this topic. Because of its nature, the study of farm tourism requires a wide spectrum of data, covering both tourism and farming. The research therefore focused on the supply (included farm tourism holders) and demand perspective (focused on potential visitors). Consequently, the empirical basis of our research was formed by creating original database via following complex qualitative and quantitative methods.

(1) A questionnaire survey of farm tourism holders (98 in 2011) in various Slovene regions and different types of rural areas. The questionnaire was focused on farmers' motives for diversification into farm tourism, relevant socio-demographic factors, future plans, etc. The respondents were farm-owners or other relevant members of farm household.

(2) Semi-structured interviews with farm tourism holders (42, including conventional and organic farmers; survey conducted in 2012). This method should give additional, indepth information on attitudes and opinions of farm tourism holders. Herewith, the selected issues were highlighted (the most important factors that shaped the decision for farm tourism, changes in family life-cycle due to farm tourism, future orientations, how tourism offer is adopted according to tourist demand, etc.).

(3) The second questionnaire survey was focused on general leisure/tourist behaviour of Slovene population (potential tourists), their motives for (not) visiting tourist farms and behaviour during visits of tourist farms. Several surveys (SORS, Turistična potovanja ... 2012; Blekesaune et al., 2008, etc.) underlined the importance of age and gender as factors for differing interests of tourists for tourist farm accommodation. Therefore, the quota sample of 440 respondents was built by taking into account the age (indicated 
categories: $15-30$ years, $31-45,46-60$, more than 60 years) and gender structure of Slovenian population.

\section{Some basic characteristics of farm tourism in Slovenia}

In Slovenia a tight connection of farm tourism and agriculture is determined by the Agriculture Act (Zakon o kmetijstvu, 2008). This Act defines the supplementary activity on active farm as an activity that is associated with agriculture (or forestry). Specific Slovenian agrarian structure plays an important role and somehow directs the development and also distribution and orientation of farm tourism. The share of employment in agriculture sector is $2.73 \%$ but with high regional disparities. Unfavourable age structure of farm holders (average farm holder in Slovenia is 57 years old) is still worsening while their education is slightly better than the average in EU 27 countries and it is gradually improving. The average Slovene farm is small, just 6.4 ha of farmland and 20,593 out of 74,646 farms (27.6\%) are smaller than 2 ha (SORS, Agriculture Census, 2010). Additionally, the land fragmentation and the unfavourable land use structure should be emphasized. The share of agricultural land is just $32.8 \%$ $(664,926 \mathrm{ha})$ and $75 \%$ of these areas are classified as less favoured areas.

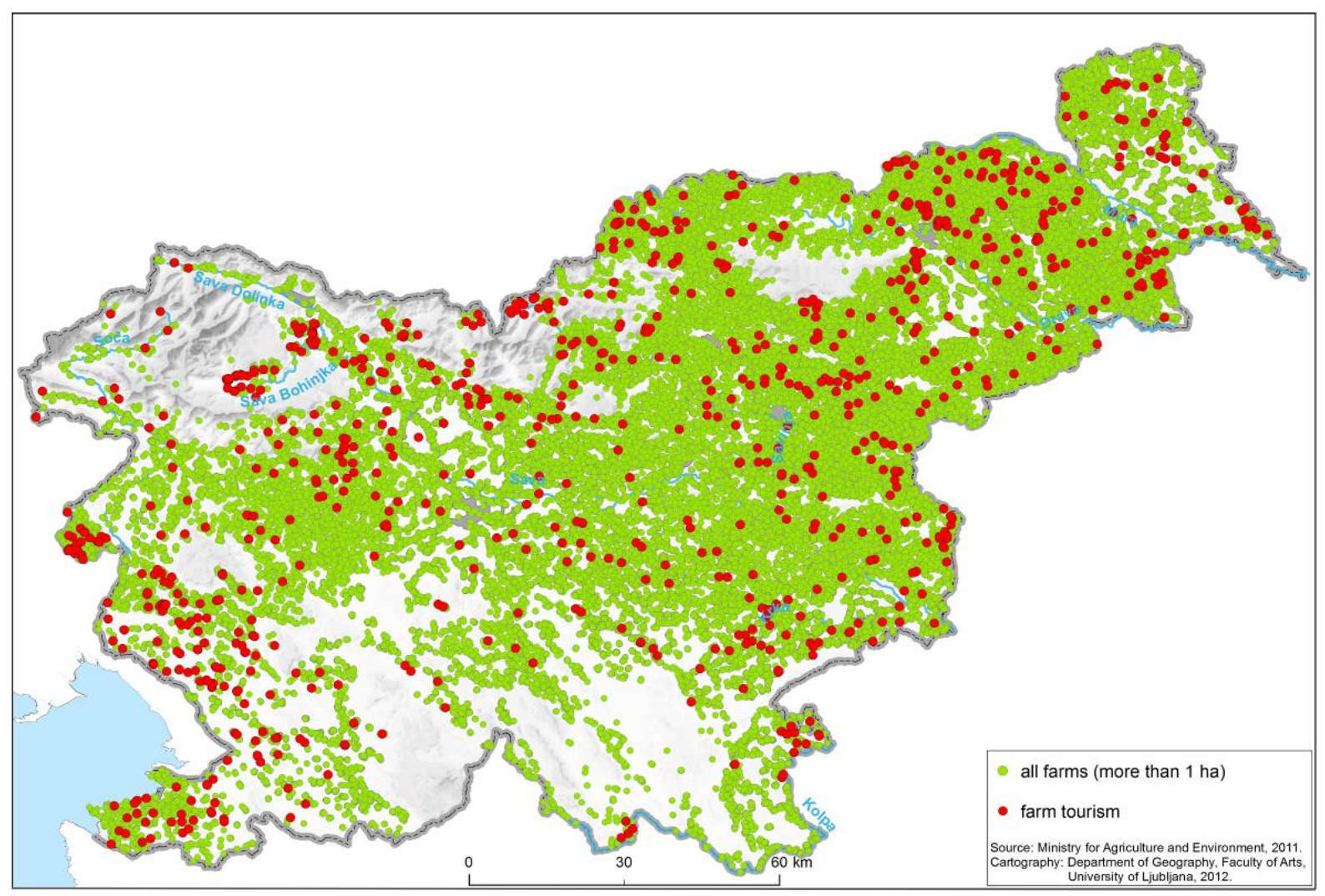

Fig 1. Distribution of tourist farms among all farms in Slovenia.

In Slovenian circumstances small scale farm tourism (regulated by the income, number of beds or seats on operating farm; Agriculture Act, 2008) has become very important activity in rural areas since it provides dispersed sites for individual employment (part- or full-time), contributes to the vitality of farm households and rural communities, and also to the maintenance of the cultural landscape, retains the population and adds value to farmers' produce and services.

SORS collects and publishes data on tourist farms with accommodation. In 2011 there were 310 tourist farms in Slovenia. Although their number is rather small it is worth mentioning that it is continuously growing. Since 2008 , when SORS started to collect data according to the new methodology, their number has increased from 236 to 310 (31\% increase) while the number of tourist beds has increased from 3,379 to 4,411 (31\% increase as well).

The second data source on farm tourism in Slovenia is the Register of Supplementary Activities, for which Ministry responsible for agriculture is in charge of. According to this register, in March 
2011 there were 371 tourist farms offering accommodation and 578 tourist farms (of different type) offering only food and beverages. Beside this, on the farms also other forms of tourism offer are available. Among them, the most frequent are tours of a farm and farm surrounding (93 farms) and provision of barbecue sites (72 farms).

Even a brief and superficial analysis of data on tourism clearly shows that tourism on farms plays - in the context of Slovenian tourism - only a minor role. In 20114411 tourist beds were available on tourist farms. This represented $3.71 \%$ of all tourist beds in the country. The importance of farm tourism is even lesser if data on tourist arrivals are taken into account. In 2011 , only 38,897 tourist arrivals were registered on tourist farms $(1.21 \%$ of all tourist arrivals in Slovenia). At least the trend is positive: in 2008 the number of tourist arrivals on tourist farms was $27,262(0.88 \%$ of all tourist arrivals). Therefore, in just three years the number of tourist arrivals has increased for $43 \%$.

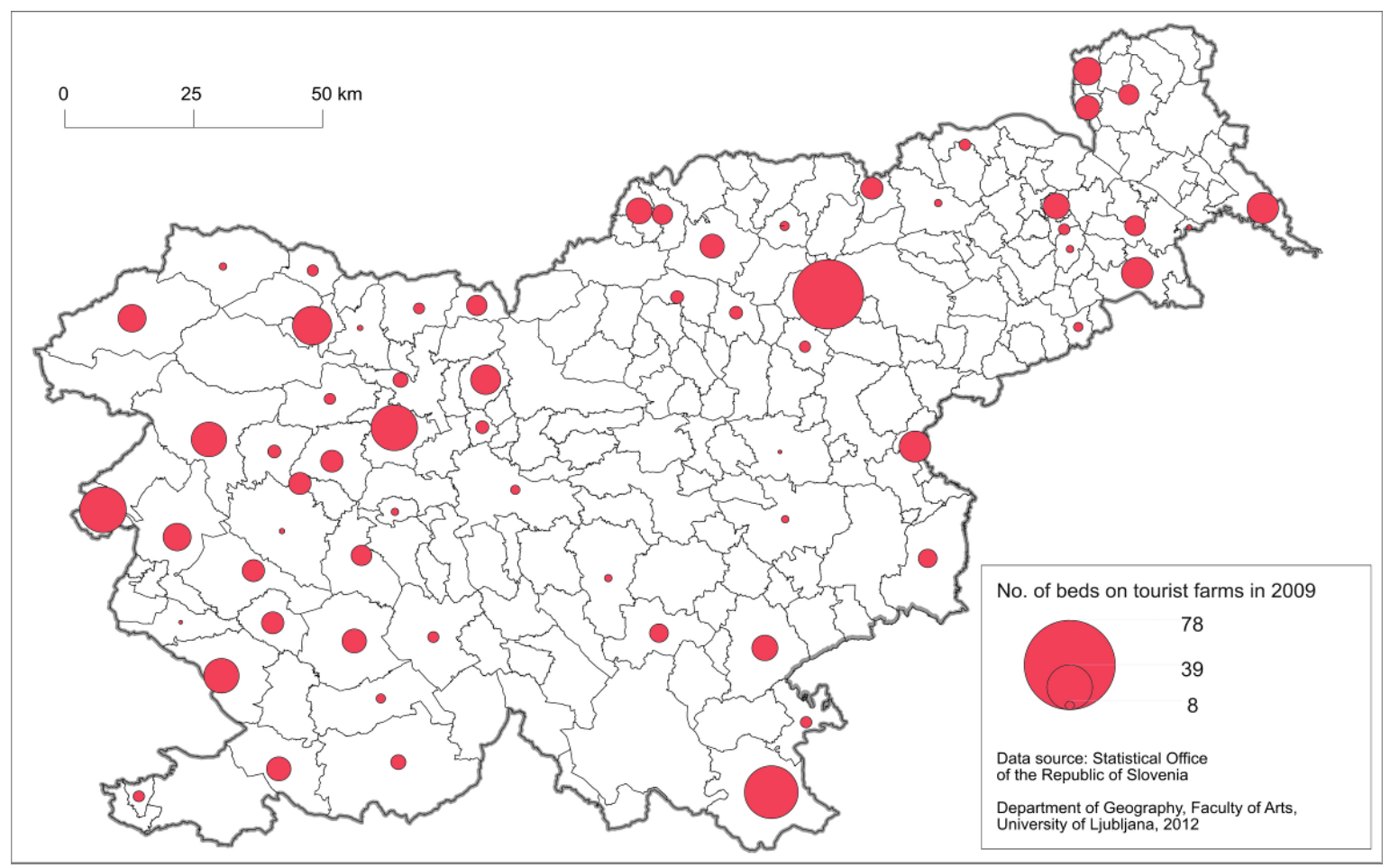

Fig 2. Number of beds on tourist farms by municipalities in 2009.

The occupancy of tourist beds on tourist farms is below the country average (7.6\% in 2009). It is a little bit higher in July (in 2009 14.2\%) and August (18.8\%). It seems that these values are low even for tourist farms (for comparison, see Oppermann 1996; De Myttenaere 2005). Additional sign of a lesser attractiveness of tourist farms is a short average length of stay. While in Slovenia the average length of stay in 2011 was 2.9 days, on tourist farms it was only 2.4 days. Obviously, tourist farms are not able to attract tourists for longer periods.

Modest attractiveness of tourist farms is, it seems, also a consequence of their spatial distribution. While hotels and similar tourist establishments concentrate in the areas, which are very attractive and especially suitable from the perspective of tourism development, no such connexion could be observed in the case of tourist farms.

According to Slovenian tourism statistics, Slovenian resorts/municipalities are categorized in six types: seaside resorts, mountain resorts, health (spa) resorts, urban municipalities, Ljubljana (Slovenia's capital) and "other municipalities". In the latter category municipalities can be found, which are not located in the regions, which are especially suitable for tourism development (coastal and mountain areas) and do not have any sources of thermal-mineral waters. Thus, municipalities without special natural tourist attractions are included in this category. Consequently, in the majority of cases also number of tourists is rather modest. 


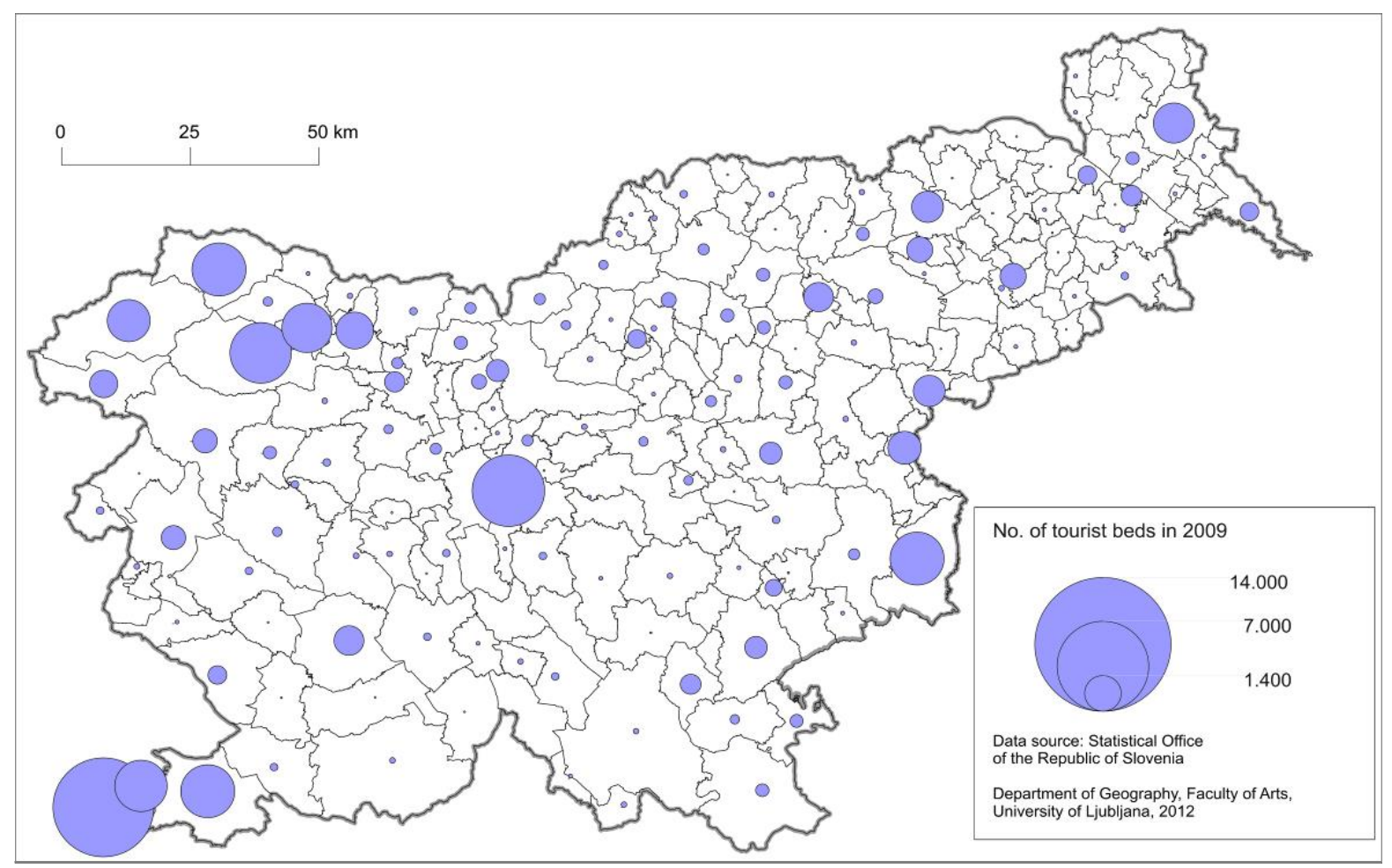

Fig 3. Number of tourist beds by municipalities in 2009.

The biggest differences in the distribution of tourist beds between tourist farms and all tourist accommodation units are in the seaside resorts/municipalities. While $20.4 \%$ of all tourist beds in the country are in the seaside municipalities, only $1.3 \%$ of beds on tourist farms are in this group of municipalities. Similarly, in health resorts there are $18.5 \%$ of all tourist beds but only $10.0 \%$ of beds on tourist farms. On the other hand, while only $14.6 \%$ of tourist beds are in "other municipalities", $54.4 \%$ of beds of Slovenian tourist farms are in these municipalities.

This clearly shows that the location of tourist farm accommodation is influenced by different factors than tourist accommodation in general. It seems that of a much bigger importance are the factors, related to supply than the ones related to the demand side. In other words: occurrence of tourist farms is primarily the result of farmers' needs and opportunities, and only on the second place of expressed demand of tourism market. This may be one of the factors, which cause lesser economic success of tourist farms. On the other hand, in the case of tourist farms criteria of economic success are different since tourism is only a supplementary (and not the main or even the only) economic activity. Its main goal is improvement of the economic situation of farming family. Additionally, the necessary investments are usually smaller. Hence, the threshold of economic viability is much lower than in the case of other tourist establishments. Additionally, diversification into tourism offers an opportunity for survival to many farms, which would otherwise be forced to abandon farming.

\begin{tabular}{|l|l|l|}
\hline Type of municipality & All tourist accommodation & Tourist farms \\
\hline Health (spa) resorts & 18,8 & 10,6 \\
\hline Mountain resorts & 32,0 & 28,2 \\
\hline Seaside resorts & 20,6 & 0,9 \\
\hline Ljubljana & 6,9 & 0,6 \\
\hline City municipalities & 7,4 & 6,4 \\
\hline Other municipalities & 14,3 & 53,3 \\
\hline SLOVENIA & 100 & 100 \\
\hline
\end{tabular}

Tab 1. Share (\%) of tourist beds by types of tourist municipalities in 2011. Source: Statistical Office of the Republic of Slovenia. 
Finally, it should be pointed out that the above analysis has included only tourist farms with accommodation, since there are no available data for tourist farms which offer only foods and beverages. Both types of tourist farms differ in their offer, labour requirements, necessary investments, seasonality of visits, etc. Therefore, it could be expected that also other differences are present.

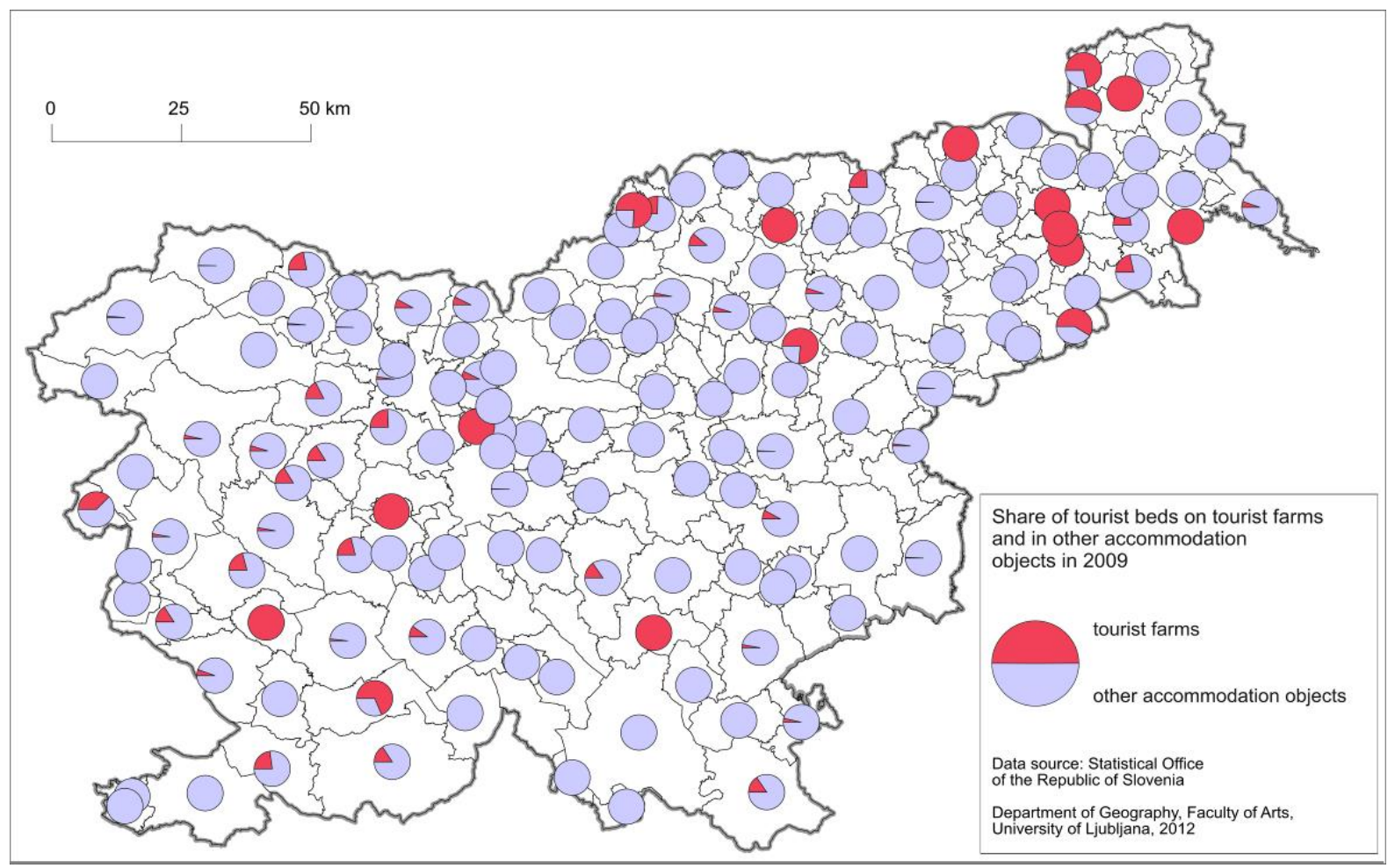

Fig 4. Share of beds on tourist farms in 2009.

\section{Results: interlinkages between farm tourism offer and demand}

The results presented below derive from qualitative surveys conducted on field in 2011 in 2012 . The analysis pointed out several structural characteristics of both, i. e. farm tourism offer and demand which enable us to focus on (non)existing linkages. Some issues relevant to future farm tourism development are highlighted.

\subsection{Farm tourism offer: mostly shaped by farm owners}

The decision for diversifying is usually a complex process, which includes external (government policy, the role of multinational companies, food-processing and food-provision chains, available subsidies, etc.) and internal factors. The latter are closely linked with the farm household. Gilg and Battershill (1999) suggested that eight factors related to farm household should be examined closely: farmer's age and education, family life-cycle, the presence of heir, the history of farming, attitude towards profit, other incomes of the family (on-, off-farm, social transfers, etc.) and work relations. How these factors influenced the decision-making process on surveyed tourist farms will be illustrated in the following paragraphs. Separately, organic farms with tourism as a supplementary activity will be discussed, since they represent a specific and important segment of farm tourism in Slovenia.

Regarding motives for farm tourism set-up the surveyed farms indicated a combination of reasons: economic motives (attaining additional income), available agricultural products (which could be processed and sold on- and off-farm), innovation and challenge, keeping up the family tradition, some follow the changes in tourist demand and use free farm buildings, skilled and disposable labour force (under-employed family members). The importance of the latter motive is evident from the average number of hours per week which are dedicated (by the farm tourism holder and other family members) to the operation of farm tourism. The figures indicated and confirmed that the type of farm tourism that is practiced in Slovenia is time-demanding (since 
numerous members of farm household indicated that "they feel exhausted"). While the holder is involved in tourism related work also during the working week, the majority of other family members (husband or spouse, younger members who are involved in secondary or university education, older members who are already retired) is included in work during week-ends and seasons.

The complex mix of above mentioned motives is illustrated by the following personal stories.

"My husband got sick so we were not able to live only from the farm. Together we decided to tourism. We are aware of an attractive location of our farm along the river, at the foot of the beautiful Slovenian mountains."

"We live on high altitude livestock farm, far from the villages and towns. Our house is huge and we said it should be suitable also for tourism. Thus, we have 20 beds, rooms and one suite. Maybe we started with tourism also because of the proximity of ski resort. "

"We learn from each visitor, they show us the way how we need to work on and what we should change, improve our offer and also attitude, relations to guests."

"On our farm we provide supplementary activities for 20 years. First of all, we had a winery, then we offered food and beverages, and then we start with different forms of processing (of agricultural products). We combine all our resources. Our guests are always coming back, but they also have their own preferences. Thus, we expand the range of our offer. If I had to decide again, I would do the same. You see, this is our life."

The farm holders which have decided to diversify in farm tourism usually hold higher education than other farm holders which diversify in other supplementary activities on farm (i. e. farm products processing, traditional bakery, services with agricultural and forestry machinery, etc.). In our survey, which included tourist farms in 11 NUTS-3 regions and 47 LAU-2 regions, $46 \%$ of farm holders hold secondary education, nearly $30 \%$ finished vocational school, and one tenth either obtained university degree or primary education. Regarding age structure, chi-square analysis revealed no significant differences between age groups (farm tourism holders are not younger). Actually, we managed to make survey on tourist farms with very long tradition (which started to operate at the beginning of 1980 s, and contemporary holder is already the second generation), and also quite numerous were the ones which started the business recently (in the last 5 to 10 years) with holders aged between 35 and 60 .

One third of surveyed tourist farms intend to enlarge services (build another apartment, offer new seats, etc.), a quarter intends to wider their farm tourism offer (new services, new foods, more added value on the farm, etc.). Since numerous surveyed tourist farms have been opened in the last ten years and they have just finished with bigger investments, it is quite understandable that $29 \%$ of surveyed farms intend to keep the status quo. $6 \%$ of tourist farms have in mind to close down mostly due to the problems with successors, one tenth is a bit sceptical about the future farm tourism development due to financial crisis, frequent regulation changes and income decrease.

We studied also driving forces for diversification into farm tourism on interviewed organic farms. Register of Supplementary Activities and Register of Organic Farms indicated that 408 (20\%) out of 2363 organic farms in Slovenia have registered at least one supplementary activity on farm. Spatial distribution of organic farms with farm tourism as a supplementary activity is conditioned by the same factors as the distribution of organic farms in general. Therefore, organic farming is strongly related to less favourable areas and due to the natural constraints farmers need to diversify their income. Organic farms prevail in Alpine and Pre-Alpine Regions where the natural amenities are in abundance; the decision for farm tourism is feasible and usually also economically appropriate decision. Organic farms decide for diversification in farm tourism more often than the conventional ones. Organic farms with accommodation prevail (72 farms), followed by organic farms offering only food and beverages (60 farms). Organic farms holders usually combine organic food production, food processing and farm tourism and in the case of crops surplus they also sell organic products (on farm). There is evident threat that supplementary activity would replace the primary farming activity. 
Qualitative research stressed the importance of farm tourism activities on the level of single farm (economic security, new business and income opportunities) and also positive impact on local development, but they have much weaker (positive) influence on regional development and wider Slovene tourism context.

\subsection{Farm tourism demand: existing farm tourism is not attractive enough}

Data of SORS show less than average attractiveness of tourist farms in comparison with other types of tourist accommodation (lower occupancy rate, shorter length of stay). In regard to this, the question arises, what are the reasons for such a situation. To find out something more about this topic, a questionnaire survey among potential and actual tourist farm visitors was conducted.

In the first part of the questionnaire, questions regarding more general characteristics of respondents' leisure behaviour were asked. The second topic, covered by the questionnaire, dealt with characteristics of respondents" tourist farm visits (e.g. their activities on farm, frequency of visits, etc.).

Special attention was given to the motives of respondents for staying/not staying on tourist farms:

- Which factors (motivations) influence the respondents in deciding to spend holidays/weekends on tourist farms and to choose a particular tourist farm?

- Which factors influence (the majority of) respondents who don't spend their holidays on tourist farm?

The respondents, who have already spent at least one night on a tourist farm, were asked to state the importance of different motives in influencing their choice of tourist farm as a preferred accommodation (on a Likert-type scale from 1 to 5 where 1 is not important at all and 5 is very important). They were also asked to select up to three most important reasons for staying on a specific tourist farm. The respondents who have not yet stayed on a tourist farm were asked to select up to three most important reasons for not staying on a tourist farm so far.

Results provide insight into the attitude of domestic tourists (Slovenian population) to farm tourism, but they could be useful also in considering ways of how to improve success of tourist farms.

The majority of respondents (47\%) spent at least one night away from home once or two times in a year; only $25 \%$ of respondents do this less than once a year. They are usually staying in hotels and similar establishments (37\%). Only $1 \%$ of respondents choose tourist farm in the majority of cases. Taking into account the statistical data on tourism, such results could be expected in advance - in 2011 only $1 \%$ of domestic tourist nights were spent on tourist farms (SORS, Nastanitvena ... 2012).

Only a quarter of respondents has already spent a night on tourist farm (at least once). In this (minority) group of respondents, the majority (49\%) has done this two to five times so far; only $16 \%$ have spent their holidays/weekends on tourist farm more than five times. Others (36\%) stayed, so far, on tourist farm only once.

Among the motives for staying on tourist farm, two were of greater importance: "good homemade food and drink" and "staying in peaceful, rural environment". Respondents evaluated the importance of different factors on the scale from 1 (not important) to 5 (very important). The average values of these factors were 3.9 and 3.7. Of above average importance were two additional factors: "more personal attitude to the guest" and "low price" (average value of 3.3). Other factors were evaluated as less important ("it was the only accommodation option in the area I was interested in" 2.2, "familiarizing with the farming way of life" 2.4, "interest in farm animals" 2.6). The latter findings are not unlike to those of Fleischer and Tchetchik (2005), who have found that the working farm does not have any special value for tourists. Also in our case the interest of visitors in some specifically agrarian characteristics of tourist farms was rather low ("familiarizing with the farming way of life", "interest in farm animals"). 
Importance of some of the motives for staying on a tourist farm increases with the age of respondents. For younger respondents, "wish to stay in a peaceful rural environment" and "more personal host-guest relationship" are less significant. In regard to the other motives, no significant correlation was found. Therefore, the nature of the demand for farm tourism holiday is correlated with age to a certain degree, but only in regard to some of the motives.

Respondents usually visit tourist farm together with "acquaintances, friends, relatives" or "family with kids" (34.2\% and 32.4\%). The former group is very well represented because of the fact that many respondents spend a night on tourist farm on the occasion of various social events, such as marriages, family reunions, anniversary celebrations, etc. It should be pointed out that members of this group are usually not among frequent visitors of tourist farms (in contrast to families with children). More than one fifth of respondents $(22.5 \%)$ visit tourist farms in the company of a partner. Very seldom, tourist farms are visited in some other type of group.

In regard to the importance of two motivations, i.e. staying in a peaceful, rural environment and good homemade food and drinks, differences between types of groups were found. Tukey HSD test showed differences between "families with kids" and "respondent and her/his partner" (for both above mentioned motives) and "families with kids" and "other" (for staying in a peaceful rural environment). In the latter case, difference is not really meaningful (or is, at least, difficult to interpret), since category "other" is comprised of very heterogeneous population (school groups, sport teams, tourists who travel alone, etc.).

\begin{tabular}{|l|r|r|r|r|r|r|}
\hline $\begin{array}{l}\text { Motives for staying on a tourist } \\
\text { farm }\end{array}$ & $\begin{array}{l}\text { family } \\
\text { with } \\
\text { kids }\end{array}$ & partner & $\begin{array}{l}\text { acquaintances, } \\
\text { friends, } \\
\text { relatives }\end{array}$ & other & & F \\
\hline $\begin{array}{l}\text { staying in peaceful rural } \\
\text { environment }\end{array}$ & 3.72 & 4.46 & 3.35 & 3.09 & 5.298 & 0.002 \\
\hline good home-made food and drink & 4 & 4.42 & 3.57 & 3.55 & 2.874 & 0.040 \\
\hline low price & 3.17 & 3.54 & 3.08 & 3.36 & 0.782 & 0.507 \\
\hline $\begin{array}{l}\text { familiarizing with the farming way } \\
\text { of life }\end{array}$ & 2.39 & 2.5 & 2.57 & 2.45 & 0.11 & 0.954 \\
\hline $\begin{array}{l}\text { more personal attitude to the } \\
\text { guest }\end{array}$ & 3.5 & 3.46 & 3.16 & 3.09 & 0.602 & 0.615 \\
\hline $\begin{array}{l}\text { Wishes of children, partner, } \\
\text { friends }\end{array}$ & 3.22 & 2.92 & 2.92 & 3.36 & 0.59 & 0.623 \\
\hline interest in farm animals & 2.75 & 2.58 & 2.58 & 2.55 & 0.122 & 0.947 \\
\hline $\begin{array}{l}\text { it was the only accommodation } \\
\text { option in the area I was interested } \\
\text { in }\end{array}$ & & & & & & \\
\hline
\end{tabular}

$T a b$ 2. Respondents' evaluation of the importance of various factors in choosing a tourist farm as a tourist accommodation (1=not important at all, 5=very important) - differences between types of groups in which respondents usually visit tourist farm (ANOVA tests). Source: Own survey, 2012 (n=440), Department of Geography, Faculty of Arts.

Better insight into the characteristics attracting tourists was offered by the question what influences respondents in choosing a particular tourist farm (see Tab. 3). Obviously, the most important factor is attractive landscape declared by $47 \%$ of respondents as one of the main reasons for their choice of a particular tourist farm, followed by location in an area of interest for tourists (38\%) and friendliness of a farm family (36\%). For $33 \%$ of respondents "positive past experience, recommendations of friends and relatives" and "favourable price" are important. For about one quarter of the respondents an important factor in choosing a particular tourist farm was proximity of a tourist resort with interesting tourism/leisure opportunities (27\%) and many recreation opportunities on the farm and in its vicinity (25\%). Other factors (tidiness and amenities of tourist farm, availability of relevant information, good traffic accessibility, cleanliness of rooms) were of lesser importance. Probably the result was influenced by the fact that some criteria are not very selective. E.g. farms, which are not accessible, cannot even start tourism activity. Also availability of information is difficult to evaluate. Tourist farms which are not known to tourists (respondents) do not, generally, even enter the selection process and are not part of the opportunity set within which they are choosing. 


\begin{tabular}{|l|c|c|c|}
\hline Reasons for choice of a particular tourist farm & $\begin{array}{c}\text { No. of } \\
\text { responses }\end{array}$ & $\begin{array}{c}\text { Percent of } \\
\text { responses }\end{array}$ & $\begin{array}{c}\text { Percent of } \\
\text { respondents }\end{array}$ \\
\hline Attractive landscape & 51 & 17.2 & 47.2 \\
\hline $\begin{array}{l}\text { Plethora of recreation opportunities on farm and in its } \\
\text { vicinity }\end{array}$ & 27 & 9.1 & 25.0 \\
\hline Favourable price & 34 & 11.4 & 31.5 \\
\hline Good accessibility (e.g. good road) & 7 & 2.4 & 6.5 \\
\hline Location in the area I am interested in & 41 & 13.8 & 38.0 \\
\hline Tidiness and amenities of tourist farm & 16 & 5.4 & 14.8 \\
\hline Cleanliness of rooms & 8 & 2.7 & 7.4 \\
\hline Friendliness of farm family & 39 & 13.1 & 36.1 \\
\hline $\begin{array}{l}\text { Vicinity of tourist resort with attractive tourism/leisure } \\
\text { opportunities }\end{array}$ & 29 & 9.8 & 26.9 \\
\hline Positive past experience, recommendations of friends, etc. & 36 & 12.1 & 33.3 \\
\hline $\begin{array}{l}\text { Accessibility of relevant information about tourist farm (e.g. } \\
\text { on internet) }\end{array}$ & 9 & 3.0 & 8.3 \\
\hline Total & 297 & 100.0 & \\
\hline
\end{tabular}

Tab 3. Factors which influenced the respondents' choice of a particular tourist farm ${ }^{2}$. Source: Own survey, 2012 ( $n=440)$, Department of Geography, Faculty of Arts.

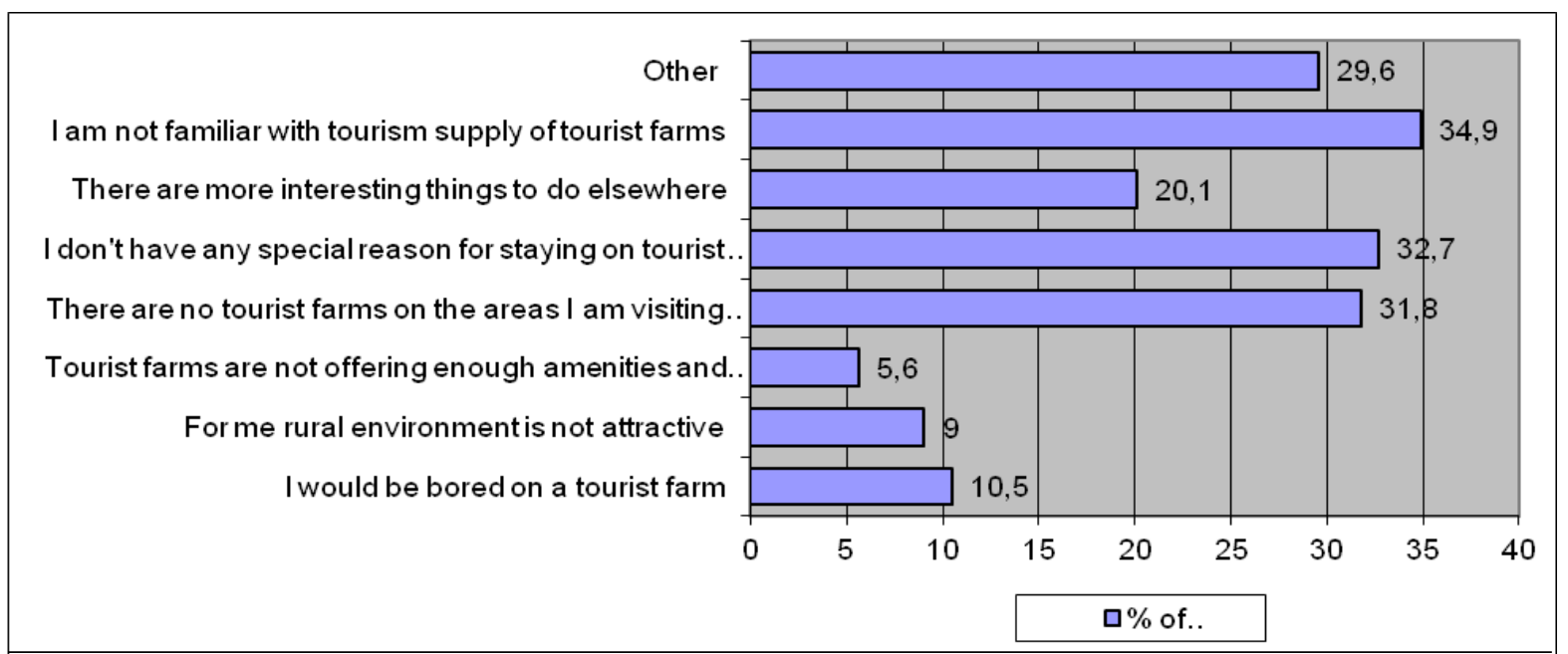

Fig 5. Reasons for not visiting tourist farms. Source: Own survey, 2012 (n=440), Department of Geography, Faculty of Arts.

Of particular interest are responses to the question, why the respondents haven't yet stayed on tourist farm. Rather surprisingly, the largest part of the respondents (34.9\%) gave the answer that they are not familiar with tourist farms' offer. $32.7 \%$ of respondents stated that they don't have any particular reason for staying on tourist farm, because rural areas don't have any special appeal to them. Similar share of respondents $(31.8 \%)$ stated that there are no tourist farms in the areas they are visiting. Many respondents gave other reasons for not staying on tourist farms, e.g. that they permanently live in rural area. Therefore, we can conclude that in the Slovenian context staying on tourist farm is, for a considerable proportion of tourists, just not interesting enough, because rural areas are part of their everyday environment - they live in the rural area or in the close proximity to it. Consequently, some additional attractions are needed in order to attract tourists. In Slovenia, there are no sharp or clear limits between urban and rural areas. Rural areas are almost ubiquitous. As a consequence, for many tourists, they cannot per se represent a tourist attraction. The same is not necessarily true for many foreign tourists who are coming from extensive urbanized areas, where they cannot have a first-hand experience of rural space. Perhaps some specificities in the structure of tourist visitors on

\footnotetext{
${ }^{2}$ Percentages are based on responses of the respondents who had already stayed on tourist farm at least once $(n=110)$. They were asked to select from the list up to three most relevant reasons for choosing a particular tourist farm.
} 
Slovene tourist farms (e.g. distinctive national structure of visitors) are the consequence of this fact.

The results have pointed out some factors which are specific for farm tourism and which are important for attractiveness of tourist farms. Some of them can be controlled by farmers themselves (e.g. the quality of tourist offer on farm) while others can be defined as external factors; farmers cannot influence them to any larger extent. Among the latter are also those related to the attractiveness of a tourist area, which depends on the range of geographical and social factors. In relation to this, establishment of close links and cooperation with other tourism and agriculture actors in the area is important as well as support of local authorities.

\section{Conclusions}

Due to the specific agrarian structure Slovenian farmers have been closely bounded to several forms of on- and off-farm diversification. Less favourable natural conditions for agriculture with small farms and fragmented agricultural land have forced farmers to earn income also from other sources on the farm or even outside the farm. Consequently, in the first part of the paper we focused on some relevant elements of agrarian structure, which have the greatest impact on the decision of farmers to diversify into tourism. Farmers' motives for such a decision are often associated with the available resources on the farm, e.g. sufficient workforce, surpluses ofcrops, availability of buildings/space, etc. (Ollenburg, Buckley, 2007; Sharpley, Vass, 2006; Dubois, Schmitz, 2011). Therefore, tourism supply to a large extent reflects existing opportunities and interests of farmers and not demands of tourism market. We should consider also the fact that usually farmers do not have previous experience with similar work. Lack of experiences, knowledge, and skills negatively affect their ability to adapt their offer to the demands of tourism market. There is not much known about expectations of tourists in regard to farm tourism. Only few researches have tackled this topic in the past more thoroughly (e.g. Blekesaune et al., 2008). Because of that, the second part of our research focused on the demand side of farm tourism, i.e. on the attitude of (potential) tourists to farm tourism.

Besides general hospitality of farms and rural areas which was common push factor for few tourist farm visitors before 1980, afterwards the stronger organized and institutionally supported development of farm tourism has taken place. Quantitative and qualitative observation of development trends on Slovenian farms emphasizes stronger interest for tourist farm openings especially in the last decade (altogether almost 900 farms offering some form of tourism). Despite this efforts farm tourism still remains supplementary activity on the farm from the income perspective as well as from tax legislation.

It has been the aim of this paper to indicate the most relevant interrelations between farm tourism offer (questionnaires conducted on 98 and interviews on 42 farms that have registered tourism as supplementary activity on the farm) and tourism demand (i. e. the potential visitors/users of farm tourism services). The common statement that tourism demand is creating/generating tourism offer is perhaps in the case of Slovenian farm tourism not that straightforward as expected.

The overall distribution of farms in Slovenia is closely connected with the heterogeneity and mosaic structure of Slovenian landscape (high landscape diversity, small and dispersed settlement pattern, etc.), but also with the former and existing agricultural (state limitations for private farming till 1991 and deagrarization, afterwards acceptance of CAP) and spatial policies (polycentric development since 1970s, quite pronounced regional disparities over the last twenty years). Consequently, the distribution of tourist farms is only partly shaped by higher tourist demand.

There is a complex mix that creates the representations of rural (also of farm tourism) amidst tourism demand. According to Halfacree (2006) there is a strong role of early perceived images and experiences of rural which usually mould the specific tourism demand for »rural idyll«. Since Slovenian rural areas have been transformed and re-structured intensively, it is quite hard if not impossible to set-up the image of »rural « that would go back for several generations. It is possible to certain degree, but there is a threat that oversimplified commodification of rural would damage the contemporary farm/rural essence. This implies that even though Slovenian 
farm tourism offer has to adapt to changing market demands, it needs to carry on the tradition which is ensuring uniqueness, authenticy and attractiveness. There is an important role of the national tourism policy and farm tourism support institutions, which should recognize the special value of the above mentioned peculiarities of farm tourism offer and also trends in tourism demand. With the proper marketing, focused promotion and other support activities they could (in)directly influence and support evolvement of (farm) tourism offer which would be in concordance with current tourism demand, but at the same time present, preserve and evaluate strong potential of authentic, not staged farm tourism and rural areas development.

However, it should not be forgotten that tourist farms are visited by tourists with different motives and expectations. Only a (smaller) part of them is looking for specifically agricultural attributes. Many tourists can be attracted to tourist farms because they are offering other attributes, e.g. the ones important in the context of outdoor recreation activities, and additionally - because of peaceful environment (in many cases far away from tourist crowds), healthy food, favourable prices, etc. In addition some other more specific tourist motivations could be satisfied on tourist farms (e.g. ecotourism in relation to tourism on organic farms) without diminishing essential qualities of farm tourism or rural areas in general.

Statements of tourist farm owners (as well as, indirectly, statistical data on farm tourism) show that reasons for diversification into farm tourism are predominantly related to economic needs of farmers and to feasibility of this decision (available working force, available buildings, etc.) and not to the especially favourable conditions for tourism development. Despite on average very low occupancy rates, tourist farm owners are not contemplating (in the majority of cases) the abandonment of the activity. On the contrary, many of them are planning extension of tourism activities. Thus we can conclude that supply does not predominantly depend on demand factors. On the other hand, tourist farm owners are taking into account perceived wishes and expectations of visitors and consequently, to an extent, adapt tourist farm offer to tourists' wishes. Therefore, supply and demand factors are interrelated in a rather complex way. Supply is only selectively influenced by (perceived) demand since farm tourism providers stick to extant idea/image of farm tourism and they are not putting it in question. In this way they also affect tourism demand since they shape a specific construct/image of farm tourism which attracts only some types of tourists.

\section{Acknowledgement}

The survey was undertaken in the framework of target project (Potentials of Supplementary Activities on Farms under reference number V5-1014, 2010-2012) co-financed by the Ministry of Agriculture and Environment and Slovenian Research Agency.

References

[1] Bengtsson, J., Ahnström, J. \& Weibull, A.-C. (2005). The effects of organic agriculture on biodiversity and abundance: a meta-analysis. Journal of Applied Ecology. 42(2), 261-269. Doi: 10.1111/j.1365-2664.2005.01005.x.

[2] Béteille, R. (1996). L'agritourisme dans les espaces ruraux européens. Annales de Géographie. 105(592), 584-602. Doi: 10.3406/geo.1996.20754.

[3] Blekesaune, A., Brandth, B. \& Haugen, M. S. (2008). Visiting a farm based tourist enterprise - who are the visitors and what is the future potential? [Paper to the $17^{\text {th }}$ Nordic Symposium in Tourism and Hospitality Research, Lillehammer, Norway, URL: http://www.bygdeforskning.no/filarkiv/2008/12/11/14940f8dde7671.pdf～(accessed 25.9. 2012).

[4] Brandth, B. \& Haugen, M. (2011). Farm diversification into tourism - Implications for social identity? Journal of Rural Studies. 27(1), 35-44. Doi: 10.1016/j.jrurstud.2010.09.002.

[5] Busby, G. \& Rendle, S. (2000). The transition from tourism on farms to farm tourism. Tourism Management. 21(6), 635-642. Doi: 10.1016/S0261-5177(00)00011-X. 
[6] Cánoves, G., Villarino, M., Priestley, G. K. \& Blanco, A. (2004). Rural tourism in Spain: an analysis of recent evolution. Geoforum. 35(6), 755-769. Doi: 10.1016/j.geoforum.2004.03.005.

[7] Cawley, M. \& Gillmor, D. (2008). „Culture economy«, »integrated tourism« and »sustainable rural development«: evidence from Western Ireland. In Robinson, G. M., ed., Sustainable Rural Systems (pp. 145-160). Adelshot: Ashgate.

[8] Choo, H. \& Jamal, T. (2009). Tourism on organic farms in South Korea: a new form of ecotourism? Journal of Sustainable Tourism. 17(4), 431-454. Doi: $10.1080 / 09669580802713440$.

[9] Clarke, J. (1996). Farm accommodation and the communication mix. Tourism Management. 17(8), 611-620. Doi: 10.1016/S0261-5177(97)84224-0.

[10] De Myttenaere, B. (2005). Dynamiques de diversification agricole et tourisme en espace rural wallon: regard sur la place des agriculteurs. UMR 6590-ESO, Colloque FAIRE CAMPAGNE, Rennes. URL: http://eso.cnrs.fr/IMG/pdf/mb-2.pdf (accessed 10.1.2011).

[11] Demonja, D. \& Ružić, P. (2010). Ruralni turizam u Hrvatskoj: s hrvatskim primjerim a dobre prakse i europskim iskustvima. Samobor: Meridijani.

[12] Dubois, C. \& Schmitz, S. (2011). The way to agritourist development from constraints to opportunities [ $19^{\text {th }}$ Annual Colloquium of the International Geographical Union Commission on the Sustainability of Rural Systems]. Galway: National University of Ireland.

[13] Dubois, C. \& Schmitz, S. (2012). Le touriste à la ferme: de la thématisation au simulacre? In Rendez-vous Champlain sur le Tourisme, l'expérience touristique: Bruxelles: Universié Libre de Bruxelles. URL: http://orbi.ulg.ac.be/request-copy/2268/123992/141288/DUBOISSCHMITZ-Champlain2012.pdf (accessed 10.6.2012).

[14] Embacher, H. (1994). Marketing for Agri-tourism in Austria: Strategy and Realisation in a Highly Developed Tourist Destination. Journal of Sustainable Tourism. 2(1-2), 61-76. Doi: 10.1080/09669589409510684.

[15] Farmaki, A. (2012). An exploration of tourist motivation in rural settings: The case of Troodos, Cyprus. Tourism Management Perspectives. 2(2-3), 72-78. Doi: 10.1016/j.tmp.2012.03.007.

[16] Fleischer, A. \& Tchetchik, A. (2005). Does rural tourism benefit from agriculture? Tourism Management. 26(4), 493-501. Doi:10.1016/j.tourman.2003.10.003.

[17] Fließbach, A., Oberholzer, H.-R., Gunst, L. \& Mäder, P. (2007). Soil organic matter and biological soil quality indicators after 21 years of organic and conventional farming.

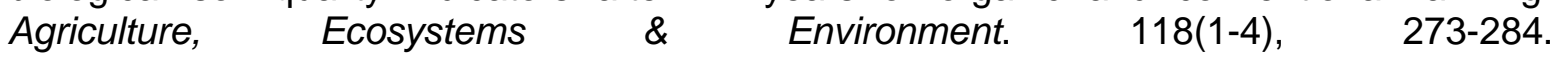
Doi: 10.1016/j.agee.2006.05.022.

[18] Frochot, I. (2005). A benefit segmentation of tourists in rural areas: A Scottish perspective. Tourism Management. 26(3), 335-346. Doi: 10.1016/j.tourman.2003.11.016.

[19] Garcia, A. \& de Magistris, T. (2007). Organic food product purchase behaviour: a pilot study for urban consumers in the South of Italy. Spanish Journal of Agricultural Research 5 (4), 439-451.

[20] Gassner, B., Freyer, B. \& Leitner, H. (2008). Labour Quality Model for Organic Farming Food Chains. In Neuhoff, D. et al., Cultivating the Future Based on Science (pp. 400-403). [Proceedings of the Second Scientific Conference of the International Society of Organic Agriculture Research]. International Society of Organic Agriculture Research.

[21] Gattermayer, F. (2006). Landwirtschaft und Tourismus. In Darnhofer, I., Walla, C., Wytrzens, H. K., eds., Alternative Strategien für die Landwirtschaft (pp. 51-61.). Wien: Facultas. 
[22] Gilg, A. W. \& Battershill, M. (1999). The role of household factors in direct selling of farm produce in France. Tidjschrift voor Economische en Sociale Geografie. 90(3), 313-319. Doi: 10.1111/1467-9663.00072.

[23] Grykień, S. (1999). Tourist farms in Lower Silesia, Poland. GeoJournal. 46(3), 279-281. Doi: $10.1023 / A: 1007056310032$.

[24] Halfacree, K. (2006). Rural space: constructing a three-fold architecture. In Handbook of Rural Studies (pp. 44-62). Thousand Oaks: Sage.

[25] Hardy, A. L. \& Beeton, R. J. S. (2001). Sustainable tourism or maintainable tourism: Managing resources for more than average outcomes. Journal of Sustainable Tourism. 9(3), 168-192. Doi: 10.1080/09669580108667397.

[26] Hummelbrunner, R. \& Miglbauer, E. (1994). Tourism promotion and potential in peripheral areas: The Austrian case. Journal of Sustainable Tourism. 2(1-2), 41-50. Doi: 10.1080/09669589409510682.

[27] Jervell, A. M. (1999). Changing patterns of family farming and pluriactivity. Sociologia Ruralis. 39(1), 100-116. Doi: 10.1111/1467-9523.00095.

[28] Kinsella, J., Wilson, S., De Jong, F. \& Renting, H. (2000). Pluriactivity as a livelihood strategy in Irish farm households and its role in rural development. Sociologia Ruralis. 40(4), 481-496. Doi: 10.1111/1467-9523.00162.

[29] Krišelj, M. (1981). Kmečki turizem na Gorenjskem. In Gorenjska: reports and material of the $12^{\text {th }}$ meeting of the Slovene geographers in Kranj and in Bled from 15th to 17th 1981 (pp. 215-220). Ljubljana: Geografsko društvo Slovenije.

[30] Lane, B. (1994). What is Rural Tourism? Journal of Sustainable Tourism. 2(1-2), 7-21. Doi: $10.1080 / 09669589409510680$.

[31] Lipič, N., Kolbl, V. \& Ovsenik, M. (2009). Primerjava modelov specializirane ponudbe turističnih kmetij $v$ Sloveniji in Avstriji. [Mednarodna konferenca o turizmu, gostinstvu in hotelirstvu. Turizem - gostinstvo - hotelirstvo v času recesije, 28. maj 2009, Čatež ob Savi]. URL: http://www.grm-nm.si/dokumenti/catez1/referati/lipic.pdf (accessed 15.12.2010).

[32] Lobley, M., Reed, M., Butler, A., Courtney, P. \& Warren, M. (2005). The Impact of Organic Farming on the Rural Economy in England. Exeter: University of Exeter.

[33] Lukić, A. (2002). Turizam naseljačkim gospodarstvima u Hrvatskoj. Dela 17, 214-229.

[34] Mäder, P., Fliessbach, A., Dubois, D., Gunst, L., Fried, P. \& Niggli, U. (2002). Soil fertility and biodiversity in organic farming. Science 296(5573), 1694-1697. Doi: 10.1126/Science.1071148.

[35] Molera, L. \& Albaladejo, I. P. (2007). Profiling segments of tourists in rural areas of SouthEastern Spain. Tourism Management. 28(3), 757-767. Doi: 10.1016/j.tourman.2006.05.006.

[36] Morrison, D., Hine, R. \& Pretty, J. N. (2005). Survey and analysis of labour on organic farms in the UK and Republic of Ireland. International Journal of Agricultural Sustainability. 3(1), 24-43. Doi:10.1080/14735903.2005.9684742.

[37] Nilsson, P. A. (2002). Staying on farms: An Ideological Background. Annals of Tourism Research 29(1), 7-24. Doi: 10.1016/S0160-7383(00)00081-5.

[38] Ollenburg, C. \& Buckley, R. (2007). Stated Economic and Social Motivations of Farm Tourism Operators. Journal of Travel Research. 45(4), 444-452. Doi: $10.1177 / 0047287507299574$.

[39] Oppermann, M. (1996). Rural tourism in Southern Germany. Annals of Tourism Research. 23(1), 86-102. Doi: 10.1016/0160-7383(95)00021-6. 
[40] Phillip, S., Hunter, C. \& Blackstock, K. (2010). A typology for defining agritourism. Tourism Management. 31(6), 754-758. Doi: 10.1016/j.tourman.2009.08.001.

[41] Schäfer, M., ed. (2007). Zukunftsfähiger Wohlstand - der Beitrag der ökologischen Landund Ernährungswirtschaft zu Lebensqualität und nachhaltiger Entwicklung. Marburg: Metropolis Verlag.

[42] Schmid, O., Sanders, J. \& Midmore, P. (ed.) (2004). Organic Marketing Initiatives and Rural Development. Aberystwyth: University of Aberystwyth.

[43] Schmitz, S. \& Potočnik Slavič, I. (2012). Development factors and Local Impacts of Agritourism: Comparison Between Slovenia and Walloon Region. In Agritourism: Between embeddedness and internationalization, Proceedings of the International Smart Conference, 14-16, June, 2012 (pp. 4-10). Ljubljana: Univerza v Ljubljani.

[44] Selfa, T., Jussaume, R. A. \& Winter, M. (2008). Envisioning agricultural sustainability from field to plate: Comparing producer and consumer attitudes and practices toward »environmentally friendly« food and farming in Washington State, USA. Journal of Rural Studies. 24(3), 262-276. Doi:10.1016/j.jrurstud.2007.09.001.

[45] Sharpley, R. \& Vass, A. (2006). Tourism, farming and diversification: An attitudinal study. Tourism Management. 27(5), 1040-1052. Doi: 10.1016/j.tourman.2005.10.025.

[46] Shreck, A., Getz, C. \& Feenstra, G. (2006). Social sustainability, farm labor, and organic agriculture: Findings from an exploratory analysis. Agriculture and Human Values. 23(4), 439-449. Doi: 10.1007/s10460-006-9016-2.

[47] Sidali, K. (2011). A sideways look at farm tourism in Germany and in Italy. In Sidali et al., eds., Food, Agri-Culture and Tourism: Linking local gastronomy and rural tourism: interdisciplinary perspectives (pp. 2-24). Berlin, Heidelberg, New York: Springer.

[48] Slabe, A., Lampič, B. \& Juvančič, L. (2011). Potenciali ekološke pridelave zatrajnostno lokalno oskrbo s hrano v Sloveniji. Dela 36, 93-109.

[49] Solsona Monzonís, J. (2006). El turismo rural en Europa. Aportes y transferencias. 10(2), 25-35.

[50] SORS (2012). Agriculture Census 2010 URL: http://pxweb.stat.si/pxweb/Database/Agriculture_2010/Agriculture_2010.asp（accessed 12.6.2012).

[51] SORS (2012). Nastanitvena statistika, letni podatki - vsi objekti. URL: http://pxweb.stat.si/pxweb/Database/Ekonomsko/21_gostinstvo_turizem/02_21645_nastani tev_letno/02_21645_nastanitev_letno.asp (accessed 10.9.2012).

[52] SORS (2012), Popis kmetijstva $2010 . \quad$ URL: http://pxweb.stat.si/pxweb/Database/Kmetijstvo_2010/Kmetijstvo_2010.asp (accessed 10.9.2012).

[53] SORS (2012). Turistična potovanja domačega prebivalstva 2010. URL: http://www.stat.si/doc/statinf/21-si-082-1101.pdf (accessed 10.9.2012).

[54] Stolze, M., Piorr, A., Häring, A. \& Dabbert, S. (2000). The environmental impacts of organic farming in Europe. Stuttgart: University of Stuttgart-Hohenheim.

[55] Storey, D. (2004). A sense of place: rural development, tourism and place promotion in the Republic of Ireland. In Holloway, L. \& Kneafsey, M., eds., Geographies of Rural Cultures and Societies (pp. 197-213). Aldershot: Ashgate.

[56] Sznajder, M., Przezbórska, L. \& Scrimgeour, F. (2009). Agritourism. Wallingford (UK), Cambridge (MA): CABI.

[57] Van der Ploeg, J. D., Renting, H., Brunori, G., Knickel, K., Mannion, J., Marsden, T., de Roest, K., Sevilla-Guzman, E. \& Ventura, F. (2000). Rural development: from practices and policies towards theory. Sociologia Ruralis 40(4), 391-408. Doi: 10.1111/1467-9523.00156. 
[58] Woods, M. (2011). Rural. Abingdon and New York: Routledge.

[59] Zakon o kmetijstvu (2008). Uradni list Republike Slovenije. 45/2008, 4965-4993. 